\title{
Contribution of Stem Cells to Neointimal Formation of Decellularized Vessel Grafts in a Novel Mouse Model
}

\author{
Tsung-Neng Tsai, ${ }^{*}$ John Paul Kirton, ${ }^{*}$ \\ Paola Campagnolo, ${ }^{*}$ Li Zhang, ${ }^{\dagger}$ Qingzhong Xiao, ${ }^{\ddagger}$ \\ Zhongyi Zhang, ${ }^{*}$ Wen Wang, ${ }^{\S}$ Yanhua Hu, ${ }^{*}$ and \\ Qingbo Xu* \\ From the Cardiovascular Division," King's College London, \\ British Heart Foundation Centre of Research Excellence, London, \\ United Kingdom; the Department of Cardiology, ${ }^{\dagger}$ First Affiliated \\ Hospital, School of Medicine, Zhejiang University, Hangzhou, \\ China; Clinical Pharmacology, ${ }^{\ddagger}$ William Harvey Research \\ Institute, Barts and The London School of Medicine and \\ Dentistry, London, United Kingdom; and the Department of \\ Engineering, Queen Mary University of London, London, \\ United Kingdom
}

Artificial vessel grafts are often used for the treatment of occluded blood vessels, but neointimal lesions commonly occur. To both elucidate and quantify which cell types contribute to the developing neointima, we established a novel mouse model of restenosis by grafting a decellularized vessel to the carotid artery. Typically, the graft developed neointimal lesions after 2 weeks, resulting in lumen closure within 4 weeks. Immunohistochemical staining revealed the presence of endothelial and smooth muscle cells, monocytes, and stem/progenitor cells at 2 weeks after implantation. Explanted cultures of neointimal tissues displayed heterogeneous outgrowth in stem cell medium. These lesional cells expressed a panel of stem/progenitor markers, including c-kit, stem cell antigen-1 (Sca-1), and CD34. Furthermore, these cells showed clonogenic and multilineage differentiation capacities. Isolated $\mathrm{Sca}-\mathrm{1}^{+}$cells were able to differentiate into endothelial and smooth muscle cells in response to vascular endothelial growth factor (VEGF) or platelet-derived growth factor (PDGF)-BB stimulation in vitro. In vivo, local application of VEGF to the adventitial side of the decellularized vessel increased re-endothelialization and reduced neointimal formation in samples at 4 weeks after implantation. A population of stem/progenitor cells exists within developing neointima, which displays the ability to differentiate into both endothelial and smooth muscle cells and can contribute to restenosis. Our findings also indicate that drugs or cytokines that direct cell differentiation toward an endothelial lineage may be effective tools in the prevention or delay of restenosis. (Am J Pathol 2012, 181:362-373; http://dx.doi. org/10.1016/j.ajpath.2012.03.021)

Neointima formation is a major concern of artificial vessel grafts and in patients with vascular disease after percutaneous coronary intervention, bypass operation, and allograft arteriosclerosis. ${ }^{1}$ It is widely accepted that increased proliferation of terminally differentiated vascular smooth muscle cells (SMCs) contribute significantly to lesional neointima formation. The origin of neointimal SMCs, however, is still debated. Initially, hypotheses suggested that they may derive from the underlying media, neighboring undamaged cells, ${ }^{2}$ and bone marrow-derived progenitor cells. ${ }^{3,4}$ More recently, experiments performed in different mouse models have shown that SMCs and endothelial cells (ECs) in atherosclerotic plaques are exclusively derived from the local vessel wall and not from the bone marrow cells. ${ }^{5-7}$ In addition to mature cells of the vessel, resident progenitor cells have been shown to be able to generate both SMCs and ECs and contribute to the neointima (as reviewed $\mathrm{in}^{8}$ ). However, the contribution of various types of cells, eg, stem/progenitor cells, to neointimal development is not fully established.

The established chimeric mouse model with bone marrow transplantation, in which bone marrow can be labeled with a specific gene, eg, $\beta$-galactosidase ( $\beta$-gal; $\mathrm{LacZ}$ ) or green fluorescent protein (GFP), ${ }^{9}$ is a method previously applied to the study of the contribution of bone marrow cells to neointimal formation. This method, how-

\footnotetext{
Supported by grants from British Heart Foundation and Oak Foundation. Accepted for publication March 27, 2012.

Supplemental material for this article can be found at $h$ ttp://ajp. amjpathol.org or at $h t t p: / / d x . d o i . o r g / 10.1016 / j$.ajpath.2012.03.021.

Address reprint requests to Qingbo Xu, M.D., Ph.D., Cardiovascular Division, King's College London, 125 Cold Harbour Lane, London SE5 9NU, UK. E-mail: qingbo.xu@kcl.ac.uk.
} 
ever, is unable to distinguish between the contribution of the resident progenitor cells in the donor vessel and the cells migrating from the vessels of the recipient. To study this specific phenomenon, we developed a mouse model using a decellularized vessel graft. The absence of cells in the grafted vessel ensures that the cells repopulating the vessel and contributing to the neointimal lesion originate from the recipient. Furthermore, a suggested advantage of the use of such a graft is that it would reduce the potential of an immune response.

To develop such a technique, methodologies must remove all cellular components from the vessel yet retain the biological and mechanical properties of the tissue. Although human saphenous vein decellularization using SDS has been demonstrated by Schaner et al, ${ }^{10}$ a defined murine model of decellularized vessel grafts has not yet been developed. In the present study, we describe a simple model wherein decellularized arteries were isografted into carotid arteries in C57BL/6J mice. We observed that decellularized vessel grafts were mostly patent within 14 days and that intimal lesions developed and progressed to marked stenosis within 4 weeks. Furthermore, we demonstrated the presence of recipient vascular stem/progenitor cells in the neointimal lesions that could differentiate into ECs and SMCs in vitro. This property was then exploited in vivo by directing EC differentiation with the local application of vascular endothelial growth factor (VEGF). Consequently, reduced SMC accumulation was observed, and the rate of neointimal formation was markedly reduced.

\section{Materials and Methods}

\section{Mice}

All animal experiments were performed according to protocols approved by the Institutional Committee for Use and Care of Laboratory Animals. C57BL/6J mice were purchased from the Jackson Laboratory (Bar Harbor, ME). Transgenic SM-LacZ mice expressing $\beta$-gal under the control of the smooth muscle-specific protein SM22 promoter have been described. ${ }^{11}$ Three genotypes of $\mathrm{LacZ}^{-/-}, \mathrm{LaCZ}^{+/-}$, and $\mathrm{LacZ}^{+/+}$mice were identified using the Jackson Laboratory's PCR protocol (primers: 5'ATCCTCTGCATGGTCAGGTC-3' and 5'-CGTGGCCTGATTCATTCC-3'). Tie2-LaCZ transgenic mice expressing $\beta$-gal under the control of the endothelialspecific protein Tie2 promoter $^{12}$ (Jackson Laboratory) were crossed to C57BL/6 mice for six generations in our laboratory before the experiments were performed. An endothelium-specific enhancer in the first intron of the mouse Tie2 gene was introduced. The combination of the Tie2 promoter with an intron fragment containing this enhancer allows it to target reporter gene expression specifically and uniformly to virtually all vascular ECs throughout embryogenesis and adulthood. The mice were maintained on a light/dark (12/12 hour) cycle at $22^{\circ} \mathrm{C}$, receiving food and water ad libitum. The genetic constitution of all mice used in the present study was C57BL/6, and all mice were bred in our laboratory.

\section{Decellularized Vessel Preparations}

The mice were sacrificed by cervical dislocation and fixed on a table. A midline incision was made, and the lung was lateralized to expose the thoracic part of the descending aorta. Perivascular tissue was removed by forceps, and intercostal arteries were ligated with a bipolar electrocoagulator (SN 54.131; Martin, Tuttlingen, Germany). The distal end of the descending aorta was then cut and washed with saline solution via puncture at the ascending aorta. The descending aorta was stored at $4^{\circ} \mathrm{C}$ in phosphate-buffered saline (PBS). The vessel was placed in $0.075 \%$ SDS solution (Sigma-Aldrich, St. Louis, MO) on a shaker for 2 hours. The vessels were then washed five times with $5 \mathrm{~mL}$ of PBS for a period of 20 minutes each on a shaker and then stored at $4^{\circ} \mathrm{C}$ in PBS plus heparin (50 $\mathrm{U} / \mathrm{mL})$.

\section{Decellularized Vessel Grafting to the Right Carotid Artery}

The recipient mouse was anesthetized by intraperitoneal injection of sodium pentobarbital $(50 \mathrm{mg} / \mathrm{kg}$ body weight), and atropine sulfate $(1.7 \mathrm{mg} / \mathrm{kg}$ body weight) was administered to prevent the obstruction of the respiratory tract by secretions. Each mouse was fixed in a supine position with its neck extended and shaved. A midline incision was made from mandible to sternum. Using a dissecting microscope (KL1500 LCD; Carl Zeiss, Jena, Germany) with 5- to 10-fold amplification, the right salivary glands were reposited laterally, and the cleidomastoid muscle was removed to expose the right common carotid artery. The right common carotid artery was mobilized free from the distal end toward the proximal end by gently removing the attached tissues. The middle portion of the common carotid artery was ligated twice with an 8-0 silk suture and dissected between the two ties. After dissecting the vessel, a cuff $(0.65 \mathrm{~mm}$ in diameter and $1 \mathrm{~mm}$ in length) made of autoclavable nylon tube (Portex, London, UK) was passed through the vessel and fixed by microhemostat clamps (Martin). The tie was then removed and a drop of heparin $(100 \mathrm{U} / \mathrm{mL})$ applied to the lumen. Following the removal of the suture, the distal end of the artery was inverted to cover the whole cuff body, and the inverted vessel was fixed with an 8-0 silk suture to the cuff; the same procedure was repeated to the other portion of the artery. Saline solution was used to flush and remove blood clots. After the cuffs were prepared, both ends of the decellularized vessel were implanted between the two ends of the carotid artery by sliding the ends of the graft over the artery cuff and fixing them with 8-0 silk sutures. The vascular clamps were removed, and the pulsation of the graft was evaluated. The right salivary gland was placed in its original position, and the skin was closed with an interrupted suture by using 6-0 polyglactin (VICRYL; Ethicon, Johnson \& Johnson, Somerville, NJ). After the procedure was completed, observation of the vital signs of the mouse was done until the mouse resumed consciousness.

For local VEGF application, the procedure used was similar to that above with the exception of VEGF (50 
$\mathrm{ng} / \mathrm{mL}$ ), mixed with pluronic F-127 gel (25\%), was applied to the outside of the grafts.

\section{Graft Harvest and Section Preparations}

The grafts were harvested in the first, second, third, or fourth postoperative weeks. The mice were anesthetized and fixed as described above. A midline incision of the neck was made, and the surrounding tissue was removed to expose the whole segment of the vessel graft and left common carotid artery. Normal saline perfusion was done from the right common carotid artery, after the left common carotid artery was cut open. The graft was harvested from the ends of the cuff and frozen in liquid nitrogen immediately. For frozen sections, the graft was embedded in optimal cutting temperature aqueous compound (VWR Scientific, Bridgeport, NJ) in a cryostat (HM 560; Microm, Walldorf, Germany) at $-20^{\circ} \mathrm{C}$. The cross sections were collected from different regions of the graft.

\section{Histology and Lesion Measurement}

The grafts were fixed with $4 \%$ formaldehyde, processed by routine histology, and then embedded in paraffin. Sections $(5 \mu \mathrm{m})$ obtained at the center of the graft were stained with hematoxylin and eosin for histological evaluation. ${ }^{13}$ The procedure for lesional area measurement is similar to that previously described. ${ }^{14,15}$ Briefly, the lesion was defined as the region between the lumen and the media. Using a transmission microscope (Zeiss), sections were scanned, saved, and then overlaid with different lines to trace the lumen and media. The lesion area was determined by subtracting the area of the lumen from the area enclosed by the line inside of the media.

\section{Creation of Chimeric Mice}

The procedure used for creating chimeric mice was similar to that described previously. ${ }^{16,17}$ Briefly, donor (SM22-LacZ, Tie2-LacZ, or wild-type) mice were sacrificed, and the femurs and tibias were removed aseptically. Marrow cavities were flushed with $\mathrm{Ca}$ - and $\mathrm{Mg}$-free Hanks' balanced salt solution (GIBCO-BRL, Grand Island, NY) using a 25-g needle attached to a syringe. Single-cell suspensions were prepared by repeat pipetting and the cell preparations passed through a nylon mesh to remove particulate matter. Cells were washed twice in Hanks' balanced salt solution, counted using a hemocytometer, and resuspended at $3 \times 10^{7}$ cells $/ \mathrm{mL}$ before transplantation. Six- to 8-week-old mice (wild type) received a lethal dose of whole-body X-ray irradiation (950 Rads) as described previously. ${ }^{16}$ The irradiated recipients received $1 \times 10^{7}$ bone marrow cells in $0.3 \mathrm{~mL}$ of RPMI 1640 by tail vein injection. Decellularized vessel grafts were performed 4 weeks after bone marrow transfer.

\section{Immunofluorescent Staining}

The procedure used for immunofluorescent staining was similar to that described previously. ${ }^{18}$ Briefly, cell smears, frozen sections, and cultured cells were labeled with rat monoclonal antibodies against Sca-1, c-kit, CD31, endothelial nitric oxide synthase (eNOS) (Abcam, Cambridge, UK), Cy3-labeled $\alpha$-smooth muscle actin ( $\alpha$ SMA), SM22 (Sigma-Aldrich), or a rabbit anti-von Willebrand factor antibody (Pharmingen/BD Biosciences, San Diego, CA), and visualized with swine anti-rabbit Ig or rabbit anti-rat Ig conjugated with fluorescein isothiocyanate (DakoCytomation, Glostrup, Denmark) or Сy3.

\section{Immunohistochemical Staining}

The procedure used in the present study was similar to that described previously. ${ }^{19}$ Briefly, serial 5 - $\mu \mathrm{m}$-thick frozen sections were overlaid with rat anti-mouse antibodies, including c-kit, Sca-1, CD34, CD31 (Abcam), CD4 (BD Biosciences, San Jose, CA), macrophage-1 antigen (MAC-1; alias CD11b/18) (Biosciences Pharmingen), and $\alpha$-SMA (Sigma-Aldrich). For $\alpha$-SMA, sections were incubated with bridging antibody rabbit anti-rat and APAAP complex (DakoCytomation) and developed using a substrate solution (Sigma-Aldrich). For the other cell markers, sections were incubated with secondary biotinylated antibody (Vector Laboratories, Burlingame, CA) and developed by $A B C$ immunochemical staining procedure (DakoCytomation). Finally, all sections were counterstained with hematoxylin (Sigma-Aldrich). Semiquantitative evaluation was performed at $\times 400$ magnification. Five sections selected from each graft were evaluated. Positive stained cells in the vessel wall were counted and expressed as the percentage of total nuclei.

\section{X-Gal Staining}

The procedure for X-gal staining was similar to that described previously. ${ }^{20}$ Briefly, vessel en face preparation, sections, and cultured cells were incubated at $37^{\circ} \mathrm{C}$ for 18 hours in PBS supplemented with $1 \mathrm{mg} / \mathrm{mL} \mathrm{X-gal} \mathrm{(Sig-}$ ma-Aldrich), $5 \mathrm{mmol} / \mathrm{L}$ potassium ferricyanide, $5 \mathrm{mmol} / \mathrm{L}$ potassium ferrocyanide, and $2 \mathrm{mmol} / \mathrm{L} \mathrm{MgCl}_{2}$. Cultures were rinsed with $3 \%$ dimethyl sulfoxide in PBS and observed under the microscope.

\section{Fluorescence-Activated Cell Sorter Analysis}

The cells were harvested by incubating with trypsin, and centrifuged briefly to obtain a cell pellet. The harvested cells were then washed with ice-cold PBS once, and centrifuged for 5 minutes at $150 \times \mathrm{g}$ and room temperature. The cell pellet was then re-suspended with $100 \mu \mathrm{L}$ of ice-cold PBS. Cells were labeled with antibodies against Sca-1, c-kit, CD34, and fetal liver kinase 1 (Flk-1) (BD Biosciences) and analyzed with a FACScan Flow Cytometer (Becton Dickinson Immunocytometry Systems, Mountain View, CA).

\section{Cell Culture and Sca- $1^{+}$Cell Isolation}

Under a dissection microscope, graft tissues were carefully harvested and prepared by removing the sur- 
rounding collective tissues. The graft tissues were cut into pieces (about $0.5 \mathrm{~mm}$ ), explanted onto a chamber slide (Nalge Nunc International, Penfield, NY), and then placed in a $5 \% \mathrm{CO}_{2}$ incubator at $37^{\circ} \mathrm{C}$ for 3 hours. Stem cell medium (ATCC, Manassas, VA) containing $10 \mathrm{ng} / \mathrm{mL}$ leukemia inhibitory factor (LIF) and 0.1 $\mathrm{mmol} / \mathrm{L}$ 2-mercaptoethanol were then added and the tissue incubated for 5 to 7 days. Media were changed every 2 days. As a control, aortic intima/media were also cultivated using the same procedure. Cell morphology and immunostaining were compared between graft and intima/media cells.

To isolate Sca- $1^{+}$cells, the primary cultured cells were applied to microbeads according to the manufacturer's instructions. Briefly, cells were dispersed with trypsin, washed with PBS containing $0.5 \%$ bovine serum albumin, and then incubated with anti-Sca-1 immunomagnetic microbeads (Miltenyi Biotec, Bergisch Gladbach, Germany). The cell suspension was added to a column equipped with a magnetic cell sorting system. After washing, Sca- $1^{+}$cells were collected. Purity and viability of isolated Sca- $1^{+}$cells were evaluated by immunostaining and Trypan Blue exclusion, respectively. Isolated cells $\left(10^{3}\right)$ in stem cell medium were seeded in a chamber slide and incubated at $37^{\circ} \mathrm{C}$ for 3 days. After trypsinEDTA treatment, $5 \times 10^{4}$ cells were seeded in a $100-\mathrm{mL}$ culture flask (BD Falcon; BD Biosciences) and incubated for 3 days. For in vitro cell differentiation, Sca- $1^{+}$cells were cultivated with Dulbecco's modified Eagle's medium supplemented with $15 \%$ fetal calf serum and mouse VEGF or platelet-derived growth factor (PDGF)-BB, 10 $\mathrm{ng} / \mathrm{mL}$ (Sigma-Aldrich), for up to 2 weeks. Mesenchymal differentiation was obtained using a Mouse Mesenchymal Stem Cell Functional Identification Kit (R\&D Systems, Minneapolis, MN) and following the manufacturer's instruction. Final staining was performed using the provided antibodies fatty acid binding protein 4 (FABP4) and osteopontin.

\section{$R T-P C R$}

The procedure used for RT-PCR was similar to that described elsewhere. ${ }^{21}$ Total RNA was prepared with the RT-PCR MiniPrep Kit (Qiagen, Valencia, CA). The primers used are summarized in Table 1.

\section{Clonogenic Assay, Characterization, and Differentiation}

To obtain single-cell cloning, DCG20 cells were trypsinized, counted, and then plated at a density of 100 cells in each gelatin-coated $10-\mathrm{cm}$ plate. Each experiment included five plates and was repeated five times. Clones were observed and counted after 14 days of growth. Cells that formed a clone were collected using 6-mm cloning disks (VWR Scientific) soaked in trypsin and then plated in 24-well plates. Clones were progressively split at $80 \%$ confluence and expanded for further applications. For each passage, the number of clones that expanded successfully was recorded.

Clones were plated 10,000 per $\mathrm{cm}^{2}$ on collagen IVcoated eight-well chamber slides, in the presence of differentiation medium ( $\alpha$-minimal essential medium + $10 \%$ fetal bovine serum) in the presence of either VEGF (50 ng/mL, endothelial differentiation) or PDGF-BB (20 $\mathrm{ng} / \mathrm{mL}$, vascular SMC differentiation) for 8 to 10 days. As a control, cells were also cultured in gelatin and embryonic stem cell medium (Dulbecco's modified Eagle's medium + LIF + 10\% fetal bovine serum; ATCC). Afterward, cells were fixed in $4 \%$ paraformaldehyde and stained for endothelial-specific [CD31, von Willebrand factor (VWF)] or SMC-specific (SMA, SM22) proteins.

\section{Western Blot Analysis}

Cells were harvested in lysis buffer $[20 \mathrm{mmol} / \mathrm{L}$ Tris-HCl (pH 8.0), $137 \mathrm{mmol} / \mathrm{L} \mathrm{NaCl}, 10 \%$ glycerol, $1 \%$ nonidet P-40, 2 mmol/L EDTA] containing protease inhibitors for

Table 1. Primer Sets Used in the Present Study

\begin{tabular}{|c|c|c|}
\hline Target & Forward & Reverse \\
\hline $\begin{array}{l}18 \text { s } \\
\alpha \text {-SMA } \\
\text { SM22 } \\
\text { Calponin } \\
\text { SM-MHC } \\
\text { CD144 } \\
\text { CD31 } \\
\text { Flk-1 } \\
\text { Flt-1 } \\
\text { vWF } \\
\text { eNOS } \\
\text { CD133 } \\
\text { CD105 } \\
\text { CD90 } \\
\text { CD44 } \\
\text { CD14 } \\
\text { CD34 } \\
\text { Sca-1 } \\
\text { c-kit } \\
\text { CD45 }\end{array}$ & $\begin{array}{l}\text { 5'-CCCAGTAAGTGCGGGTCATAA-3' } \\
\text { 5'-TCCTGACGCTGAAGTATCCGAT-3' } \\
\text { 5'-GATATGGCAGCAGTGCAGAG-3' } \\
\text { 5'-GGTCCTGCCTACGGCTTGTC-3' } \\
\text { 5'-AAGCAGCCAGCATCAAGGAG-3' } \\
\text { 5'-AAGAAACCGCTGATCGGCA-3' } \\
\text { 5'-CAAACAGAAACCCGTGGAGATG-3' } \\
\text { 5'-TGAAATTGAGCTATCTGCCGG-3' } \\
\text { 5'-TTTCAACACCTCCGTCATGT-3' } \\
\text { 5'-GGCTGTGCGGTGATTTAACAT-3' } \\
\text { 5'-CTGAGGGTGTCGTAGGTGATG-3' } \\
\text { 5'-TTAAACCAGGAGCTGCCCAAG-3' } \\
\text { 5'-CACAACAGGTCTCGCAGAAA-3' } \\
\text { 5'-GCCAACTTCACCACCAAGGA-3' } \\
\text { 5' } \\
\text { 5'-TATCCTCGTCACGTCCAACA-3' } \\
\text { 5'-GCTTGTTGCTGTTGCTTCTG-3' } \\
\text { 5'-CCACAGACTTCCCCAACTG-3' } \\
\text { 5'-TCTGAGGATGGACACTTCTC-3' } \\
\text { 5' } \\
\text { 5'TCCCAGAAACAGGCTGAGTT-3' } \\
\text { 5'AATACTGGCCAAGCATGGAG-3' }\end{array}$ & 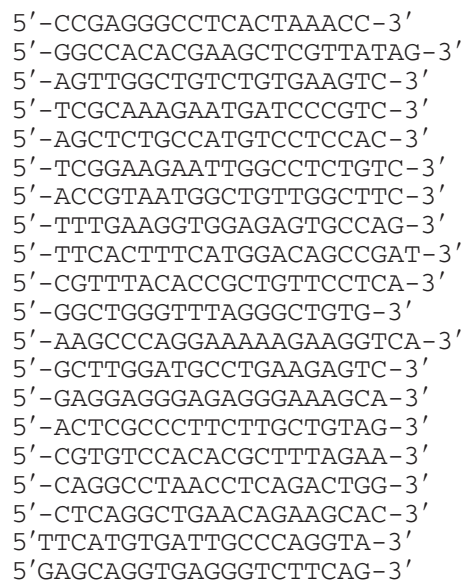 \\
\hline
\end{tabular}

SM-MHC, smooth muscle myosin heavy chain. 

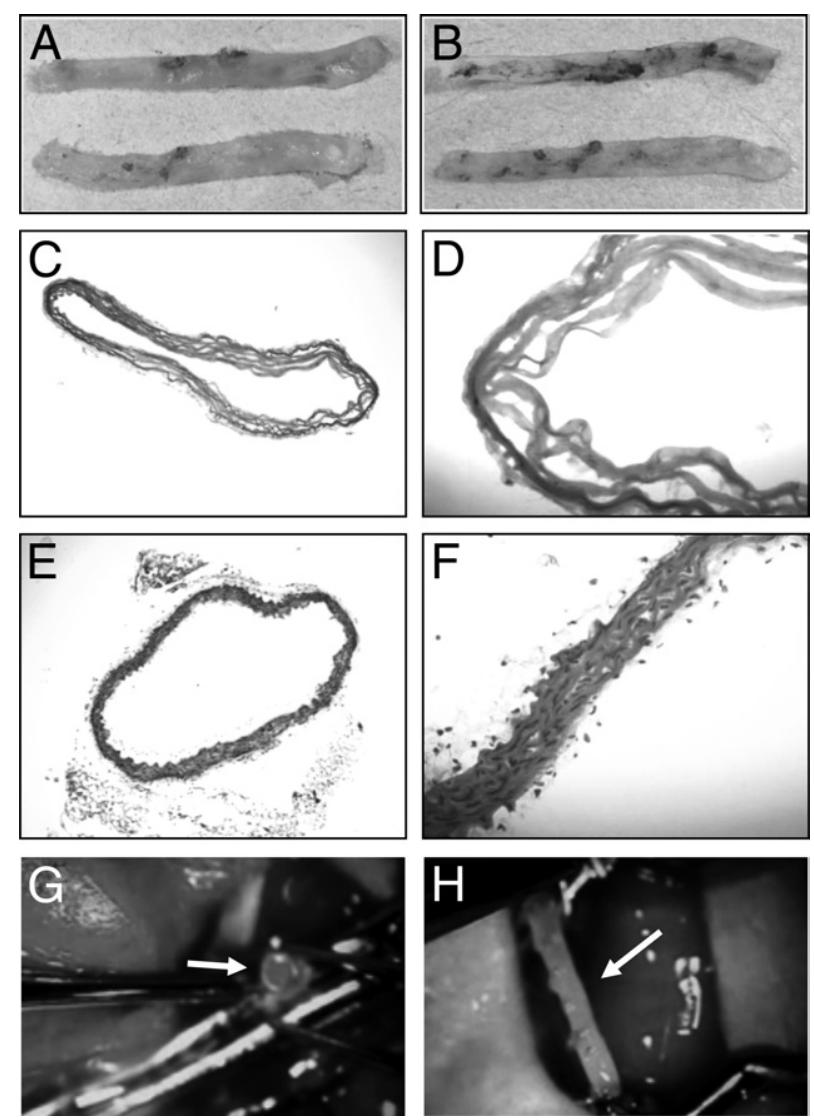

Figure 1. Decellularized mouse thoracic aorta preserves its structure (A) and resembles a normal vessel (B). Hematoxylin and eosin staining shows complete removal of cells in the treated vessel (C and $\mathbf{D})$ as compared to controls (E and $\mathbf{F}$ ). Panels $\mathbf{G}$ and $\mathbf{H}$ show decellularized vessel grafting. The images are representatives from 10 vessels/group. Arrows indicate the cuff $(\mathbf{G})$ and vessel graft $(\mathbf{H})$. Original magnification: $\times 2(\mathbf{A}$ and $\mathbf{B}) ; \times 50(\mathbf{C}$ and $\mathbf{E}) ; \times 200$ (D) and $\mathbf{F}$ ).

the whole-cell lysate. Forty micrograms of protein was separated by SDS-PAGE on a $4 \%$ to $12 \%$ Tris-glycine gel (Invitrogen, Carlsbad, CA), transferred to nitrocellulose transfer membranes (Schleicher \& Schuell Bioscience, Dassel, Germany), and then subjected to standard Western blot analysis.

\section{Statistical Analysis}

Statistical analyses were performed on a Macintosh computer using the Mann-Whitney $U$-test and analysis of variance. $P<0.05$ was considered significant.

\section{Results}

\section{Characterization of Decellularized Graft Model}

We achieved whole-aorta decellularization by treatment with SDS, an anionic detergent that lyses cells and solubilizes cytoplasmic components. After 2 hours of decellularization, a translucent acellular scaffold, which retained the gross shape of the vessel, was generated (Figure 1A) and was compared to a fresh harvested aorta (Figure 1B). Histological evaluation revealed no nuclei or cytoplasmic staining in decellularized vessels (Figure 1, C and D) compared to a normal mouse aorta (Figure 1, E and F). Moreover, immunostaining for endothelial marker CD31 and $\alpha$-SMA was completely negative in the decellularized vessels (data not shown).

Using a cuff technique previously established in our laboratory, ${ }^{13}$ we successfully grafted the decellularized vessel to the right carotid artery of C57BL/6J mice; grafted vessels did not show any leaking (Figure 1, G and
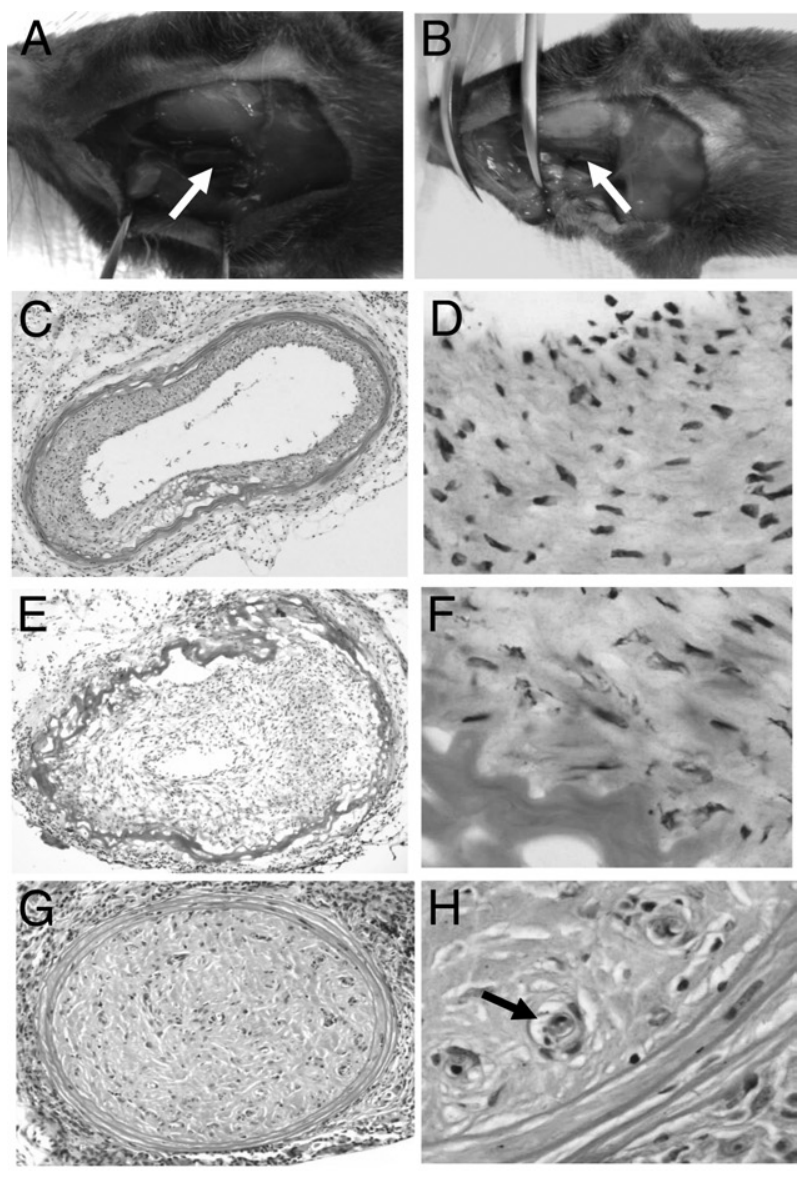

\section{I}

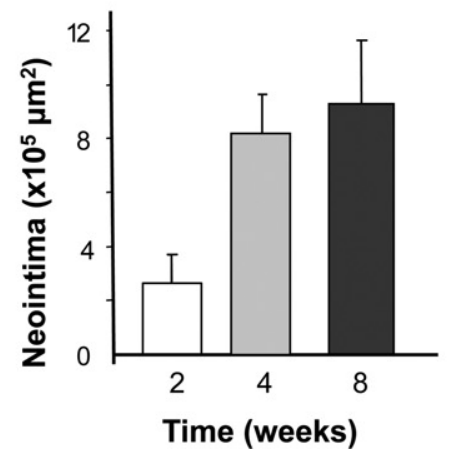

Figure 2. Progression of the graft in vivo. The decellularized vessels are mostly patent 2 weeks after grafting (A) but blocked after 4 weeks (B); the arrowhead indicates the lumen. Formation of the neointima lesion is observed at $2(\mathbf{C}$ and $\mathbf{D}), 4(\mathbf{E}$ and $\mathbf{F})$, and $8(\mathbf{G}$ and $\mathbf{H})$ weeks after surgery. The sections at the different levels of grafts were collected, and neointimal areas were quantified. I: Quantitative data (means \pm SD) are presented $(n=6$ per group). The arrowhead indicates a microvessel $(\mathbf{H})$. Original magnification: $\times 50(\mathbf{C}, \mathbf{E}$, and $\mathbf{G}) ; \times 400(\mathbf{D}, \mathbf{F}$, and $\mathbf{H})$ 
H). Survival rate after grafting was usually high (>90\%). Development of the graft was followed over time, and samples were collected at different time points for downstream analysis. Two weeks after bypass surgery, the majority of the grafted vessels were functioning with blood flow and pulsations (Figure 2A; see also Supplemental Video S1 at http://ajp.amjpathol.org). Interestingly, this situation dramatically changed at week 4, when most grafts were found almost completely obstructed (Figure 2B).

Histological analysis showed rapid neointimal thickening after 2 weeks (Figure 2, C and D), which resulted in extreme narrowing of the lumen at 4 weeks (Figure 2, E and F) and blockage at 8 weeks (Figure 2, G, H, and I). Immunohistochemistry analysis showed two major changes associated with thickening of the neointimal lesion: reduced mononuclear cell infiltration and increased matrix protein accumulation. This was clearly evident in sections from 8-week lesions, which clearly showed a reduced cell number when compared to sections from earlier time points, along with abundant matrix protein accumulation and microvessel formation (Figure 2, $\mathrm{G}$ and $\mathrm{H}$ ).

\section{Cell Composition in Neointimal Lesions}

To analyze the cell populations participating in the development of neointima hyperplasia of decellularized vessel grafts, sections of 2- and 4-week-old grafts were stained for SMC marker $\alpha$-SMA, leukocyte marker MAC-1
(CD11b/18), T-cell marker CD4, and progenitor cell markers (c-kit, Sca-1, and CD34). As expected, the control sections incubated with Ig did not show any positive staining (Figure $3 \mathrm{~A}$ ). Results showed the presence of abundant SMCs in vessel graft lesions at 2 and 4 weeks after surgery, which constituted the majority of cells within lesions (Figure 3, B and I). Interestingly, we observed $\alpha-\mathrm{SMA}^{+}$SMCs also in the media, between matrix fiber (Figure $3 \mathrm{C}$ ), and in the adventitia in proximity to the media (Figure 3D). MAC-1 staining showed an abundant infiltration of monocyte/macrophages in the intimal lesion at 2 weeks after engraftment, which decreased after 4 weeks (Figure 3, E and I). Furthermore, abundant infiltrating MAC-1-positive cells were also found in the adventitia (Figure 3F), whereas the media was almost devoid of staining (data not shown).

In addition, $\mathrm{CD} 4^{+} \mathrm{T}$ cells were found in the neointimal lesions of 2-week grafts (Figure 3G), and rarely in late grafts (data not shown). Putative CD $31^{+}$endothelial cells were observed in the luminal surface of most areas in vessel grafts and were occasionally seen even before neointimal formation (Figure $3 \mathrm{H}$ ). Surprisingly, we found that neointimal lesions of the vessel graft contained large numbers of cells positive for progenitor marker such as Sca-1, c-kit, and CD34 (Figure 3, J-M). Our results indicate that SMC accumulation is a main cell component and that some progenitors are present at the site of lesions in decellularized vessel grafts in our mouse model.
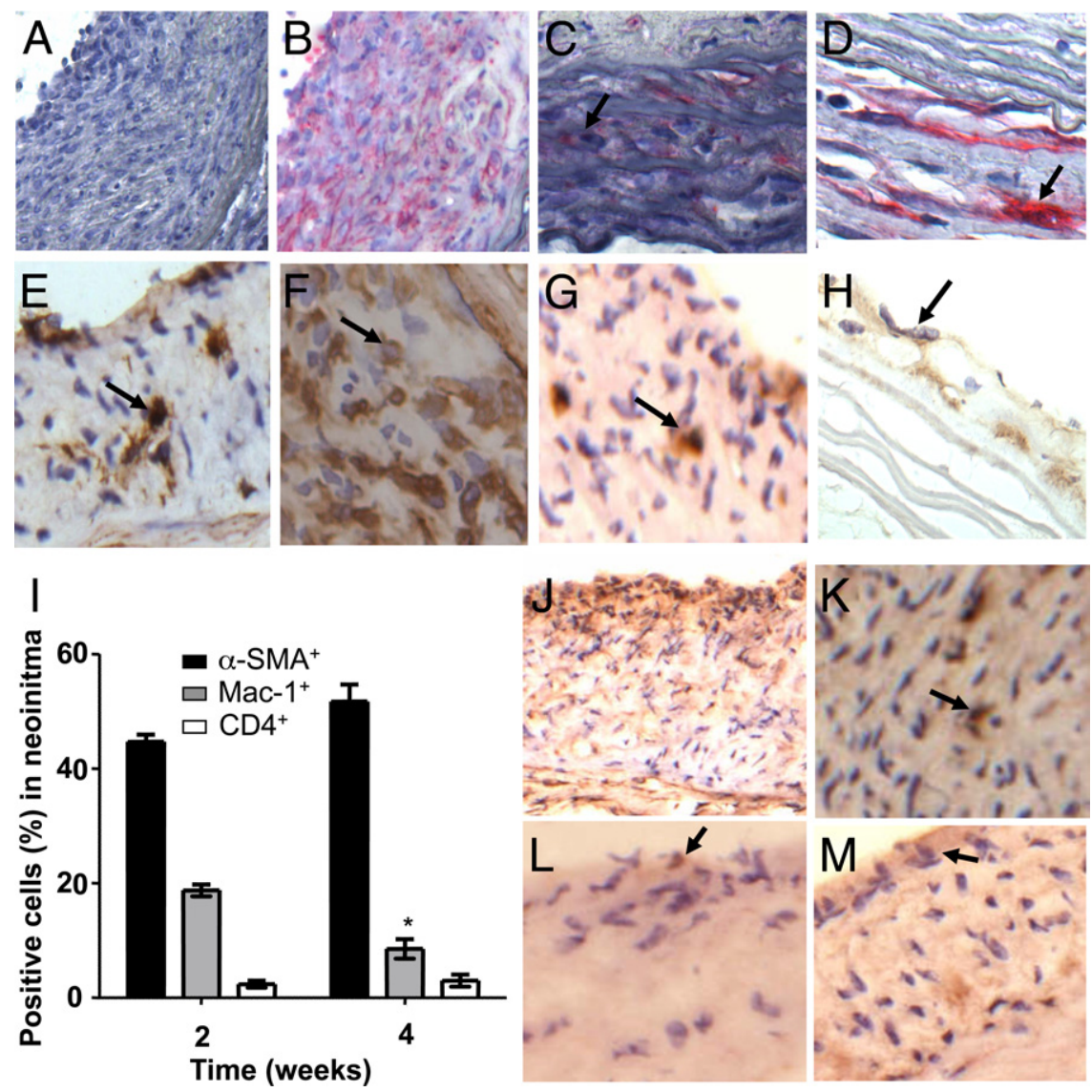

Figure 3. Cellular composition of the lesion. Immunohistochemical staining shows localization of $\alpha-\mathrm{SMA}^{+}$smooth muscle cells in the in tima (B), media (C), and adventitia (D) $\mathrm{com}^{-}$ pared to the control (A). Cells in the lesion also included $\mathrm{MAC}^{+}$macrophages $(\mathbf{E}$ and $\mathbf{F}), \mathrm{CD}^{+}$ $\mathrm{T}$ cells $(\mathbf{G})$, and $\mathrm{CD} 31^{+}$endothelial cells $(\mathbf{H})$. I: Quantification of cellular components of the neointima lesion are shown $[5$ sections through each graft, means $\pm \mathrm{SD}(n=6)]$. J-M: Immunohistochemical staining for Sca- $1^{+}(\mathbf{J}$ and $\mathbf{K})$,

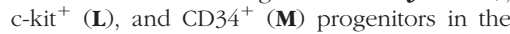
lesion. Arrows indicate positive cells. Original magnification, $\times 400$. 

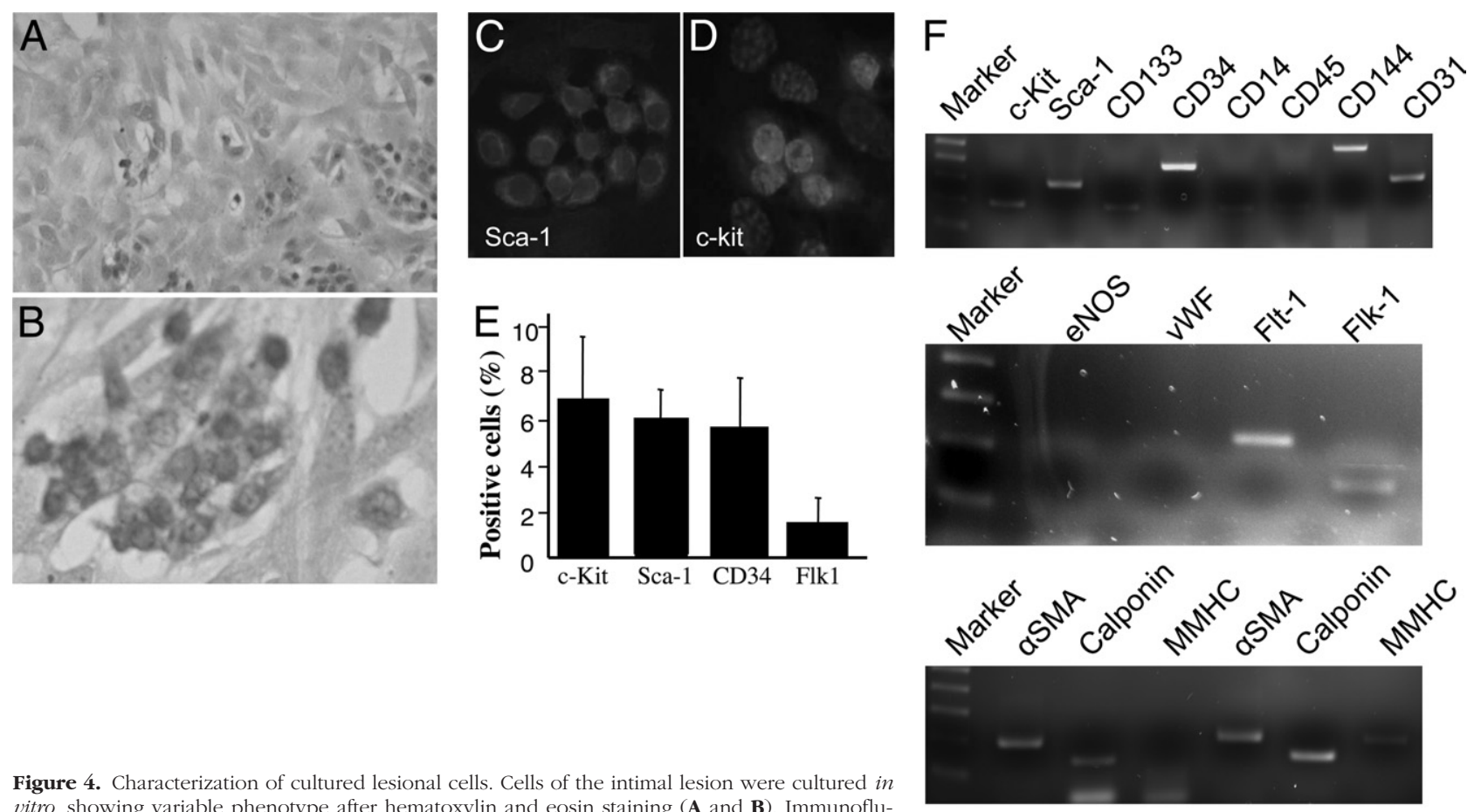

Figure 4. Characterization of cultured lesional cells. Cells of the intimal lesion were cultured in vitro, showing variable phenotype after hematoxylin and eosin staining ( $\mathbf{A}$ and $\mathbf{B}$ ). Immunofluorescence for Sca-1 (C) and c-kit (D) and flow cytometry (E, c-kit, Sca-1, and CD34, and Flk-1) confirmed the presence of cells expressing progenitor markers. F: RT-PCR indicates the expression of a wide range of progenitor and vascular markers. Original magnification: $\times 200(\mathbf{A}) ; \times 400$ (B-D).

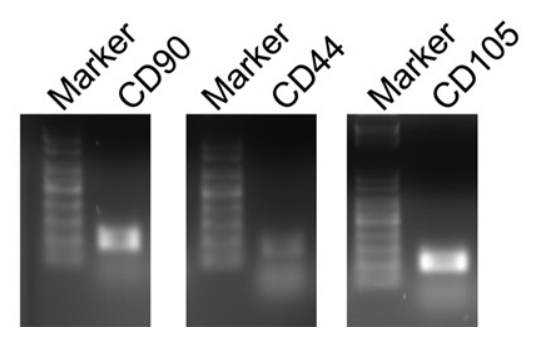

\section{Non-Bone Marrow Origin of Lesional SMCs and Endothelial Cells}

To confirm whether lesional SMCs are derived from the bone marrow in our model, a chimeric mouse was created by transplanting SM22-LacZ bone marrow into a wild-type C57BL6 mouse. In this model, bone marrowderived SMCs and SMC progenitor cells do express LacZ gene under the regulation of the SM22 promoter. Specificity of the expression in the transgenic mice was confirmed by $\beta$-gal staining of SMCs in aortic sections (see Supplemental Figure S1A at http://ajp.amjpathol.org). Six weeks after bone marrow reconstruction, a decellularized vessel was grafted into the chimeric mice. Sections obtained from 2-week-old grafts were stained with X-gal, and the absence of $\beta$-gal ${ }^{+}$cells was confirmed (see Supplemental Figure S1B at http://ajp.amjpathol.org). In vitro studies confirmed that cells obtained from the grafts implanted in chimeric mice receiving SM22-LacZ bone marrow were negative for $\beta$-gal (see Supplemental Figure S1C at http://ajp.amjpathol.org). As expected, cells in control grafts implanted into SM22-LacZ mice displayed positive staining (see Supplemental Figure S1D at http:// ajp.amjpathol.org). Taken together, these results indicate that SMCs in the neointimal lesions are not derived from bone marrow cells.
Similarly, a chimeric mouse model was established using Tie2-LacZ transgenic mice, ie, transplanting Tie2LacZ bone marrow cells to irradiated wild-type mouse with the same genetic background. Six weeks after bone marrow reconstruction, a decellularized vessel was grafted into the chimeric mouse. The sections labeling for $\beta$-gal ${ }^{+}$cells confirmed that cells obtained from the grafts implanted in chimeric mice receiving Tie2-LacZ bone marrow were negative for $\beta$-gal (see Supplemental Figure $\mathrm{S} 2, \mathrm{~A}-\mathrm{C}$, at http://ajp.amjpathol.org), indicating that bone marrow cells may not contribute to the formation of endothelium in the decellularized grafts.

\section{Characterization of Cultured Vascular Progenitor Cells}

To isolate putative progenitors contained among the heterogeneous population of cells within the decellularized vessel graft, explants were plated and cultured in stem cell medium. Cells migrating from the explants showed different morphologies, including large fibroblast-like cells and small clusters of round cells (Figure 4, A and B). Immunofluorescence showed that clusters were formed by cells positive for the progenitor markers Sca-1 and c-kit (Figure 4, C and D); quantification by flow cytometry 
A

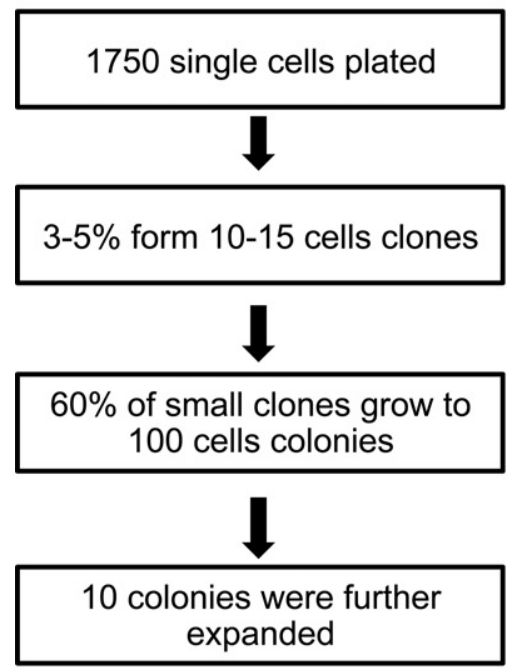

B

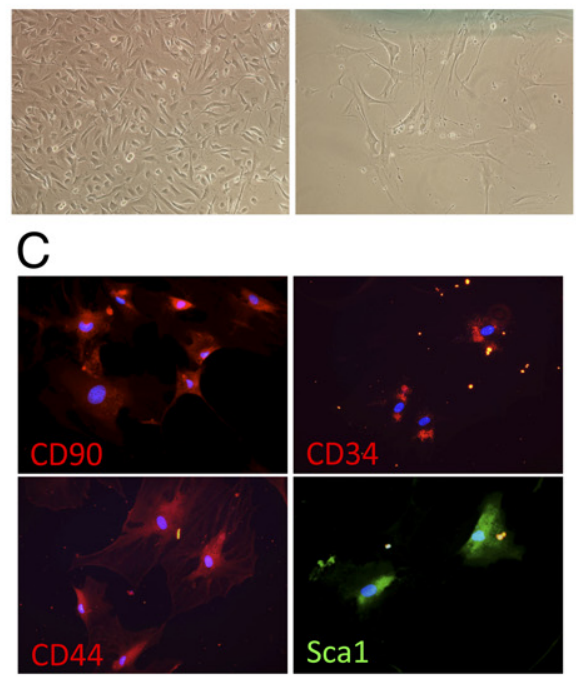

Figure 5. Clonogenic assay and differentiation of lesional cells. A: Cells were cloned by limiting dilution; approximately $3 \%$ to $5 \%$ of cells formed clones that could be gradually expanded. B: As shown by representative microphotographs (five times), the clones appeared highly heterogenic. C: Clones were tested for expression of stem cell markers by immunocytochemistry. After expansion, 10 clones reached a cell number greater than $10^{5}$, and 3 of them were used for differentiation assays. $\mathbf{D}$ and $\mathbf{E}$ : Clones showed differential capacity in giving rise to EC and SMC populations. Original magnification: $\times 100(\mathbf{B})$; $\times 200(\mathbf{C}$ and $\mathbf{E})$

showed that the total population was indeed composed of about $7 \%$ of $\mathrm{c}-\mathrm{kit}^{+}$and approximately $6 \% \mathrm{Sca}-1^{+}$and $\mathrm{CD}^{+} 4^{+}$cells (Figure 4E). Furthermore, PCR analysis confirmed expression of progenitor markers and revealed limited expression of hematopoietic markers (Figure 4F). As expected, these cells also expressed endothelial and smooth muscle markers, eg, CD31, CD144, $\alpha$-SMA, and calponin (Figure 4F). Importantly, cells grown in stem cell medium expressed mesenchymal stem cell markers (CD105, CD90, CD44) (Figure 4F) and were able to undergo osteogenic and adipogenic differentiation, although they did not show chondrogenic differentiation potential (Figure 4F; see also Supplemental Figure S3, A-F, at http:// ajp.amjpathol.org). These findings implicate the presence of several progenitor cell populations within the cells forming the lesion, that can be cultivated and expanded in vitro.

\section{Clonogenic and Differentiation Potential of Isolated Progenitor Cells}

We next investigated whether lesional cells were clonogenic by conducting a limiting dilution assay. In these conditions, $3 \%$ to $5 \%$ of cells formed colonies after 10 to 15 days of culture (Figure 5A). The morphology of the cells appeared to be extremely variable among the colonies, suggesting that several subpopulations of progenitors are present in the recellularized graft (Figure 5B). Although gene expression analysis confirmed variability between isolated clones, all displayed lower levels of c-kit and higher expression of Sca-1 when compared to the whole population. In particular, one clone showed high expression of mesenchymal markers
(CD90, CD44, CD105) and vasculogenic progenitor cell markers (Sca-1 and CD34) as compared to the whole population, whereas another clone only overexpressed CD44 and CD105 (Figure 5, C and D). Three clones were tested for their ability to give rise to ECs and/or SMCs. Results showed that each clone displayed a different differentiation capacity (Figure 5, D and E). Altogether, the results indicate that cells derived from the vessel lesion are clonogenic and that the clones are multipotent.

\section{Isolation and Differentiation of Sca- ${ }^{+}$Cells}

Clonogenic cells isolated from the lesion-derived population showed strong expression of Sca-1 stem cell marker and could differentiate into ECs and SMCs. To assess whether lesion-derived progenitor cells might be derived from the same progenitor population, Sca- $1^{+}$ cells were isolated from primary cultures with immunomagnetic beads. Selection yielded a population composed of at least $80 \%$ Sca- $1^{+}$cells, largely coexpressing c-kit $^{+}$(data not shown). To confirm the progenitor phenotype of these Sca- $1^{+}$cells, we tested their ability to differentiate into ECs and SMCs. Isolated cells cultured in collagen IV-coated plates in the presence of VEGF, showed a strong increase in endothelial marker gene expression, including eNOS, vWF, CD31, CD144, and VEGF receptors1/2 (Figure 6A). Western blot analysis revealed a significant increase in endothelial markers Fmslike tyrosine kinase 1 (Flt-1) and eNOS $(P<0.05)$, whereas immunofluorescence labeling confirmed positive staining for endothelial marker proteins (Figure 6, B and C). 
A

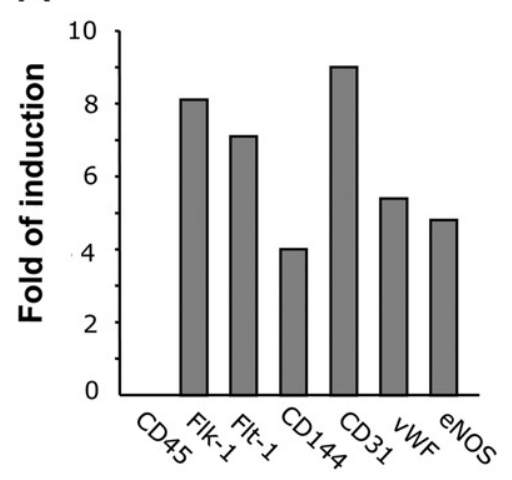

B

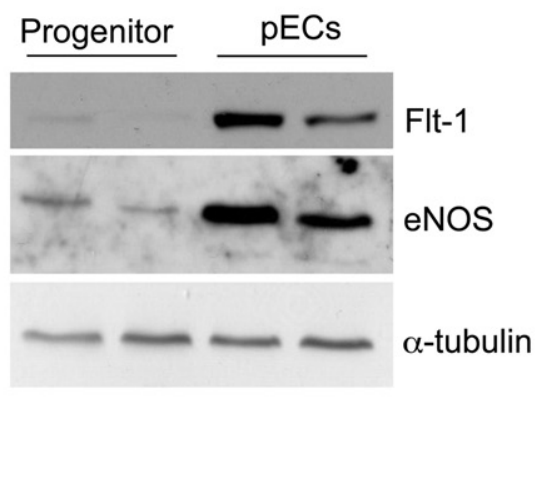

E
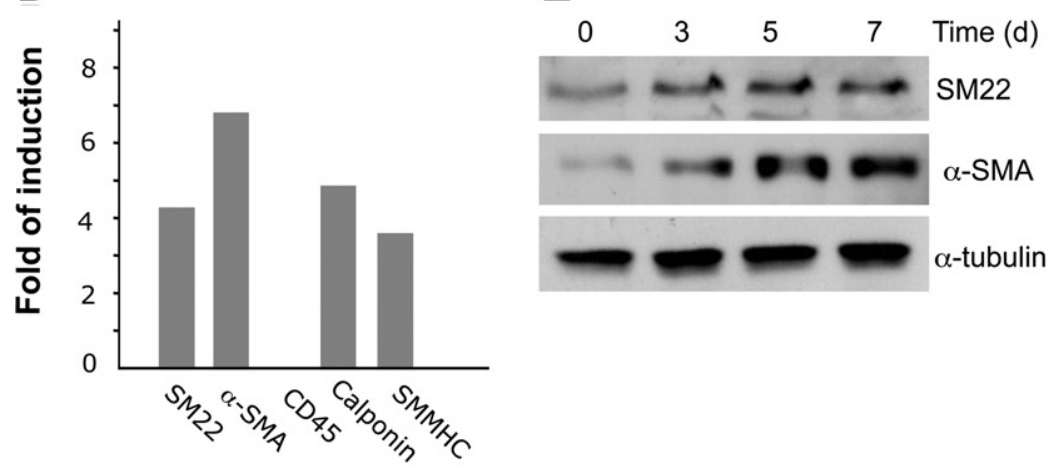

C
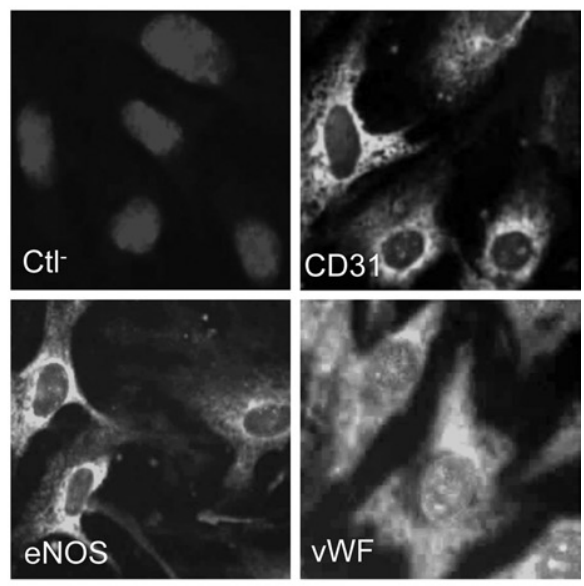

F
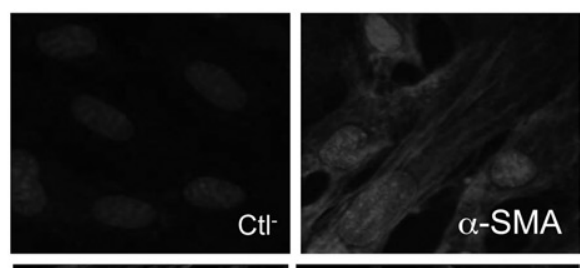

$\alpha$-tubulin
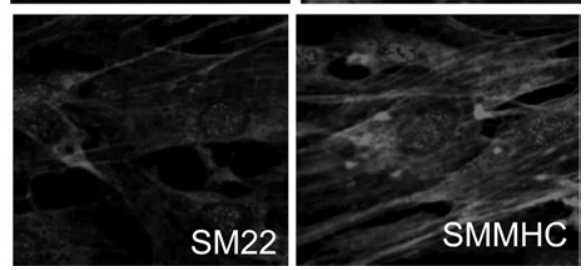

Figure 6. Isolated Sca- $1^{+}$progenitor cells are able to differentiate into ECs and SMCs. Sca- $1^{+}$cells were isolated with microbeads and cultured in the presence of VEGF or PDGF for 7 days. VEGF-dependent EC differentiation was verified by quantitative PCR (A and $\mathbf{B})$, Western blot analysis (B), and immunostaining (C), Data are representative of three experiments. Treatment with PDGF increases SMC marker expression as shown by quantitative PCR (D), Western blot analysis (E), and immunostaining (F). Nuclei were counterstained with Hoechst 33258 (blue). The data are representative from three similar experiments. Original magnification, $\times 400 . \mathrm{Ctl}^{-}$, control.

Similarly, these progenitor cells could differentiate into the SMC phenotype when they were treated with PDGF$\mathrm{BB}$, as shown by increased expression of SMC markers at both mRNA and protein levels (Figure 6, D-F). On the other hand, when Sca- $1^{+}$progenitors were cultured in SMC differentiation medium, endothelial marker genes, including CD31, VWF, and eNOS, did not significantly increase as identified by PCR and Western blot analysis (see Supplemental Figure S4 at http://ajp.amjpathol.org). These results suggest that Sca- $1^{+}$cells derived from the lesion can differentiate into ECs and SMCs in vitro.

\section{Local VEGF Application Reduces Neointimal Lesions}

In vitro results showed that VEGF is able to promote preferential differentiation of lesional progenitor cells toward endothelial lineage; we decided to investigate its potential application in vivo. Using an established protocol, ${ }^{22}$ VEGF was mixed with pluronic F-127 gel and applied locally to envelope the decellularized vessel grafts implanted into Tie2-LacZ mice. Tie2 expression by ECs was verified by LacZ staining performed on the vessels of the transgenic mice (data not shown). Local treatment with VEGF enhanced $\beta$-gal ${ }^{+}$EC localization to the surface of decellularized vessels (Figure 7A) as compared to untreated controls at 1 week (Figure 7B). Furthermore, neointimal formation in decellularized vessel grafts were markedly inhibited in the VEGF-treated group at 4 weeks (Figure 7C) as compared to the untreated group (Figure 7D). The lesions formed in the grafted vessel were measured and showed that local VEGF treatment reduced neointimal thickness by up to $80 \%$, when compared to untreated controls (Figure 7E). These results indicate that local VEGF treatment can dramatically reduce neointimal development in this mouse model of vessel grafting.

\section{Discussion}

Recently, many investigators have developed murine genetic models in which genes are overexpressed, deleted, or mutated to study the development of the neointima during arteriosclerosis. ${ }^{23}$ In the present report, we establish and characterize a new model for the study of neo- 

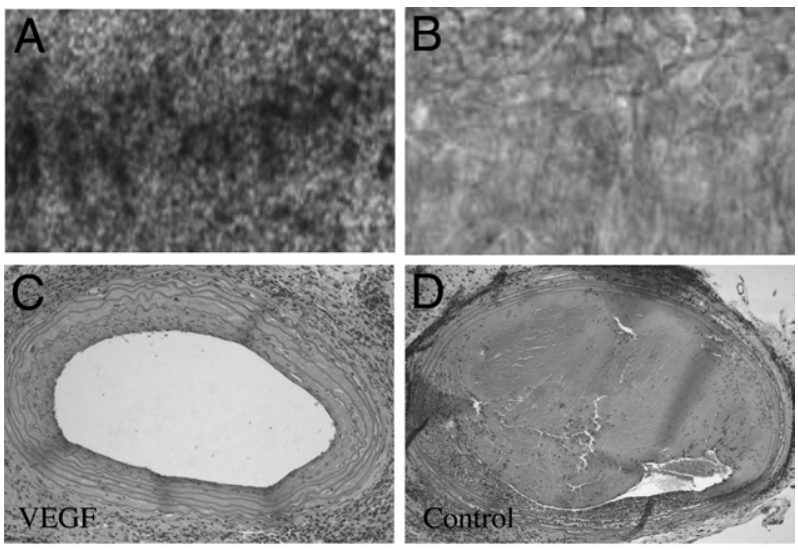

$\mathrm{E}$

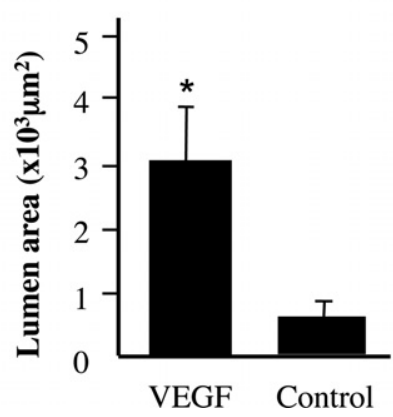

Figure 7. Effect of local application of VEGF in vessel grafts in vivo. Representative images show typical VEGF-treated $(\mathbf{A})$ and control (B) grafts with en face preparation and X-gal development. Cross sections of the treated $(\mathbf{C})$ and untreated control (D) grafts were stained with hematoxylin and eosin. Original magnification, $\times 50$. E: Lumen size was calculated on sections from graft tissues obtained 4 weeks after surgery. Animals treated locally with VEGF show significantly increased lumen size as compared to untreated controls. Data are means $\pm \mathrm{SD}(n=6) .{ }^{*} P<0.001$ versus control.

intima formation using decellularized vessel grafts in mice, which ultimately allowed us to study the contributory effect of the cells of the recipient. Using this model, we successfully cultivated and characterized the cells that contribute to neointimal lesion formation. Moreover, we have provided evidence that a number of these cells display stem/progenitor capabilities. Importantly, these cells possess the two fundamental properties of stem cells, clonogenicity and multipotency, and as such can differentiate into ECs and SMCs. Interestingly, local VEGF application can enhance EC phenotype differentiation in the vessel grafts. These findings could be a significant development toward understanding the potential effects of the stem cells on vascular pathophysiology, and could also have an implication for therapeutic possibilities by directing cell differentiation in vivo.

In the present report, we establish and characterize a new model for the study of neointima formation of decellularized vessel grafts in mice. In some respects, the morphological features of neointimal lesions in this murine model of decellularized vascular grafts resemble those of human vessel graft disease or restenosis after angioplasty. For instance, both the human and mouse lesions are characterized by concentric intimal proliferation with a dominance of SMCs in late specimens. ${ }^{24} \mathrm{Hu}$ man lesions have an inflammatory nature characterized by mononuclear cell infiltration in the early stage of neo- intimal formation ${ }^{25}$; similarly, the lesions seen in our mouse models contain abundant MAC- $1^{+}$monocytes/ macrophages. Thus, this model could be useful in the study of neointimal development in human disease. For example, when used with vessel grafts in mice subjected to targeted gene deletion, the model could provide a powerful tool for dissecting the relative contributions of such genes, including low-density lipoprotein receptors, endothelial adhesion molecules, and growth factors, in the development of neointima hyperplasia. 26,27 Additionally, decellularized vessel grafts can be efficiently treated locally or ex vivo with drugs or gene transfer, as shown by our results with VEGF. In particular, the thinner vessel wall of decellularized vessels allows easy penetration of small molecules and plasmids from the adventitia side. ${ }^{19} \mathrm{Fi}$ nally, the decellularized vessel could be an excellent scaffold for preparing a tissue-engineered vessel by cell seeding on the inner surface. To test this theory, we have performed preliminary experiments using the decellularized vessel seeded with induced pluripotent stem (iPS)derived ECs and SMCs to reconstruct an artificial vessel. This tissue-engineered vessel displayed normal functional properties with minimal neointimal lesion formation (unpublished data, T.-N.T., J.P.K., P.C., L.Z., Q.X., Z.Z., W.W., Y.H., Q.X.). By using this model, we believe that significant progress in understanding the pathogenesis and treatment of neointimal lesions may be seen in the near future.

Because cell origin in neointimal lesions is a fundamental issue for understanding the pathogenesis as well as the development of potential therapeutic interventions, we approached the characterization of these cells using our model. We successfully cultivated and characterized the lesional cells and provided the first evidence that abundant stem/progenitor cells in the lesions can differentiate into ECs and SMCs. Furthermore, we demonstrated that lesional cells possess two fundamental properties of stem cells, clonogenicity and multipotency. Seminal reports described the presence of progenitor cells in the vessel wall of transplanted organs. ${ }^{8}$ To the best of our knowledge, the present study is the first to demonstrate the isolation and characterization of stem/ progenitor cells from mouse neointimal lesions. We used specific surface markers, namely Sca-1, to achieve enhanced purity and reproducibility. The differentiation of Sca- $1^{+}$cells gave rise to ECs and SMCs. Importantly, a clonogenic and multipotent cell population can be obtained from heterogeneous cell cultures of neointimal cells, which could be expanded for at least 10 passages and could be cryopreserved easily. The differentiation capacity of these cells is not limited to vascular cells but is extended also to osteoblasts and adipocytes, other cells types found to contribute to different stages of atherosclerosis. These results might implicate a stem cell origin, at least in part, for neointimal cells and might give an alternative explanation to the observation that SMCs in the neointima lesion display a specific migratory and proliferative phenotype due to their function. ${ }^{28-30}$ In fact, SMCs in neointimal lesions might display a variety of phenotypes that differ from medial SMCs due to their 
origins, ie, stem/progenitor cells, representing different differentiation stages.

The origin of lesional cells is still debated; many reports from different laboratories indicate that a variety of cell sources contribute to lesion formation. ${ }^{5,6,16,17,31-34}$ One of them is bone marrow, which can release stem cells able to migrate and differentiate into SMCs. ${ }^{9} \mathrm{Al}-$ though earlier studies reported that a large proportion of lesional SMCs are derived from bone marrow, ${ }^{3,4,9,35}$ our results obtained by using a SMC-specific reporter (SM22) transgenic mouse model showed no evidence of bone marrow stem cells differentiating into SMCs within neointimal lesions of decellularized vessel grafts. Using a similar SMC reporter gene (smooth muscle myosin heavy chain) in a transgenic model, Iwata et al ${ }^{36}$ concomitantly demonstrated that bone marrow cells cannot differentiate into mature SMCs in neointimal lesions. Thus, bone marrow cells are unlikely to be a main source of neointimal SMCs.

The second source of neointimal cells is the vessel wall. We previously found that about $60 \%$ of SMCs in atherosclerotic lesions of vein grafts were derived from the vessel wall. ${ }^{16,17}$ It is well accepted that medial SMCs can migrate to the intima where they proliferate and accumulate to form the lesions. Contribution of the donorderived SMC to the neointima can be excluded in our model, due to the use of decellularized vessel grafts. As such, there are only three potential sources in which the neointimal SMCs found to repopulate the decellularized vessel could come from: cells resident within the tissue surrounding the decellularized vessel grafts, cells from the recipient arterial wall, and circulating blood released from non-bone marrow tissues. Previously, we reported the presence of adventitial progenitor cells that can migrate across the vessel wall, contributing to SMC accumulation in atherosclerotic lesions of vein grafts in $A p o E^{-/-}$mice. $^{37}$ In our decellularized vessel model, it could also be possible that tissue-resident cells may also pass through the matrix protein layers to accumulate in the intima. In addition, SMCs in the media of carotid arteries might directly migrate along the matrix layer of grafted vessels into the intima.

It was observed that one feature of the lesion development in decellularized grafts is inflammatory response, eg, mononuclear cell infiltration and the presence of $\mathrm{T}$ cells. How was the inflammation initiated? At present, it is unknown. Given the fact that decellularized vessels are exposing matrix proteins to the blood, platelets can be activated on the surface of the grafts, resulting in thrombosis formation. It is well known that activated platelets could release chemokines/cytokines, eg, RANTES, platelet factor 4 (CXCL4), epithelial neutrophil-activating protein 78 (CXC chemokine ligand 5), $\mathrm{IL}-1 \beta$, and stromal-derived factor 1 (SDF-1), ${ }^{38}$ which can attract inflammatory cells to infiltrate the thrombosis/ neointima. When activated, platelets coaggregate with circulating leukocytes. ${ }^{39}$ Once adherent to the vascular wall, platelets also provide a sticky surface to recruit leukocytes to the vessel wall. These could be an explanation for the inflammatory response in the grafts of the mouse models. Clinically, severe endothelial damage oc- curs in some vessel grafts, eg, transplant arteriopathy, followed by microthrombosis formation and inflammatory response. The present animal model could be useful for studying thrombosis and inflammation in vessel grafts in the future.

For many years, we followed the hypothesis that the proliferation of SMCs from the media is responsible for restenosis formation, by which we designed a drug-eluting stent to inhibit SMC proliferation, but the outcome of a long-term clinic trail showed a risk for thrombosis. ${ }^{40}$ The possible reason is that inhibition of SMC growth is concomitantly inhibiting endothelial and progenitor cell proliferation. The present findings demonstrate the presence of stem cells in neointimal lesions that can differentiate into both endothelial and smooth muscle cells, which may offer a new explanation and provide new direction for potential therapeutic intervention for restenosis. Support for this notion is the experimental result of local VEGF treatment, ie, VEGF promoted re-endothelialization and reduced neointimal lesions in decellularized vessel grafts. In fact, VEGF therapy to reduce restenosis has already been carried out in clinical trials, in which it has been proposed to have an effect on proliferation and increased eNOS production. ${ }^{41}$ In the present study, our results imply that additional mechanisms of VEGF-enhanced re-endothelialization may be involved in precursor differentiation. Additional investigations focusing on this issue will be needed in the future. We suggest that promotion of EC, as opposed to SMC, proliferation of the abundant progenitor cells invading the decellularized graft can enhance the rate of re-endothelialization, which in turn would effectively inhibit further SMC proliferation/ differentiation and reduce lesion development. Therefore, our studies provided some clarification on the cell types that contribute to the developing neointima using our novel decellularized vessel model. As such, this could provide direction for future clinic applications for patients after angioplasty.

\section{References}

1. Schwartz SM: The intima: a new soil. Circ Res 1999, 85:877-879

2. Ross R, Glomset J, Harker L: Response to injury and atherogenesis. Am J Pathol 1977, 86:675-684

3. Saiura A, Sata M, Hirata Y, Nagai R, Makuuchi M: Circulating smooth muscle progenitor cells contribute to atherosclerosis. Nat Med 2001, 7:382-383

4. Sata M: Circulating vascular progenitor cells contribute to vascular repair, remodeling, and lesion formation. Trends Cardiovasc Med 2003, 13:249-253

5. Bentzon JF, Sondergaard CS, Kassem M, Falk E: Smooth muscle cells healing atherosclerotic plaque disruptions are of local, not blood, origin in apolipoprotein E knockout mice. Circulation 2007, 116:2053-2061

6. Bentzon JF, Weile C, Sondergaard CS, Hindkjaer J, Kassem M, Falk $\mathrm{E}$ : Smooth muscle cells in atherosclerosis originate from the local vessel wall and not circulating progenitor cells in ApoE knockout mice. Arterioscler Thromb Vasc Biol 2006, 26:2696-2702

7. Hagensen MK, Shim J, Thim T, Falk E, Bentzon JF: Circulating endothelial progenitor cells do not contribute to plaque endothelium in murine atherosclerosis. Circulation 2010, 121:898-905

8. Torsney E, Xu Q: Resident vascular progenitor cells. J Mol Cell Cardiol 2011, 50:304-311 
9. Sata M, Saiura A, Kunisato A, Tojo A, Okada S, Tokuhisa T, Hirai H, Makuuchi M, Hirata Y, Nagai R: Hematopoietic stem cells differentiate into vascular cells that participate in the pathogenesis of atherosclerosis. Nat Med 2002, 8:403-409

10. Schaner PJ, Martin ND, Tulenko TN, Shapiro IM, Tarola NA, Leichter RF, Carabasi RA, Dimuzio PJ: Decellularized vein as a potentia scaffold for vascular tissue engineering. J Vasc Surg 2004, 40: $146-153$

11. Moessler H, Mericskay M, Li Z, NagI S, Paulin D, Small JV: The SM 22 promoter directs tissue-specific expression in arterial but not in venous or visceral smooth muscle cells in transgenic mice. Development 1996, 122:2415-2425

12. Schlaeger TM, Bartunkova S, Lawitts JA, Teichmann G, Risau W, Deutsch U, Sato TN: Uniform vascular-endothelial-cell-specific gene expression in both embryonic and adult transgenic mice. Proc Natl Acad Sci U S A 1997, 94:3058-3063

13. Zou Y, Dietrich H, Hu Y, Metzler B, Wick G, Xu Q: Mouse model of venous bypass graft arteriosclerosis. Am J Pathol 1998, 153:13011310

14. Dietrich H, Hu Y, Zou Y, Dirnhofer S, Kleindienst R, Wick G, Xu Q: Mouse model of transplant arteriosclerosis: role of intercellular adhesion molecule-1. Arterioscler Thromb Vasc Biol 2000, 20:343-352

15. Dietrich H, Hu Y, Zou Y, Huemer U, Metzler B, Li C, Mayr M, Xu Q: Rapid development of vein graft atheroma in ApoE-deficient mice. Am J Pathol 2000, 157:659-669

16. Hu Y, Davison F, Ludewig B, Erdel M, Mayr M, Url M, Dietrich H, Xu $\mathrm{Q}$ : Smooth muscle cells in transplant atherosclerotic lesions are originated from recipients, but not bone marrow progenitor cells. Circulation 2002, 106:1834-1839

17. Hu Y, Mayr M, Metzler B, Erdel M, Davison F, Xu Q: Both donor and recipient origins of smooth muscle cells in vein graft atherosclerotic lesions. Circ Res 2002, 91:e13-e20

18. Mayr U, Mayr M, Li C, Wernig F, Dietrich $H, H u$ Y, Xu Q: Loss of p53 accelerates neointimal lesions of vein bypass grafts in mice. Circ Res 2002, 90:197-204

19. Hu Y, Zou Y, Dietrich H, Wick G, Xu Q: Inhibition of neointima hyperplasia of mouse vein grafts by locally applied suramin. Circulation 1999, 100:861-868

20. Hu Y, Baker AH, Zou Y, Newby AC, Xu Q: Local gene transfer of tissue inhibitor of metalloproteinase-2 influences vein graft remodeling in a mouse model. Arterioscler Thromb Vasc Biol 2001, 21:1275-1280

21. Yamashita J, Itoh $\mathrm{H}$, Hirashima M, Ogawa M, Nishikawa S, Yurugi T, Naito M, Nakao K: Flk1-positive cells derived from embryonic stem cells serve as vascular progenitors. Nature 2000, 408:92-96

22. Torsney E, Mayr U, Zou Y, Thompson WD, Hu Y, Xu Q: Thrombosis and neointima formation in vein grafts are inhibited by locally applied aspirin through endothelial protection. Circ Res 2004, 94:1466-1473

23. Xu Q: Mouse models of arteriosclerosis: from arterial injuries to vascular grafts. Am J Pathol 2004, 165:1-10

24. O'Brien ER, Alpers CE, Stewart DK, Ferguson M, Tran N, Gordon D, Benditt EP, Hinohara T, Simpson JB, Schwartz SM: Proliferation in primary and restenotic coronary atherectomy tissue. Implications for antiproliferative therapy. Circ Res 1993, 73:223-231

25. Schwartz RS, Henry TD: Pathophysiology of coronary artery restenosis. Rev Cardiovasc Med 2002, 3(Suppl 5):S4-S9
26. Detmers PA, Hernandez M, Mudgett J, Hassing H, Burton C, Mundt S, Chun S, Fletcher D, Card DJ, Lisnock J, Weikel R, Bergstrom JD, Shevell DE, Hermanowski-Vosatka A, Sparrow CP, Chao YS, Rader DJ, Wright SD, Pure E: Deficiency in inducible nitric oxide synthase results in reduced atherosclerosis in apolipoprotein $\mathrm{E}$-deficient mice. J Immunol 2000, 165:3430-3435

27. Palinski W, Ord VA, Plump AS, Breslow JL, Steinberg D, Witztum JL: ApoE-deficient mice are a model of lipoprotein oxidation in atherogenesis. Demonstration of oxidation-specific epitopes in lesions and high titers of autoantibodies to malondialdehyde-lysine in serum. Arterioscler Thromb 1994, 14:605-616

28. TCampbell JH, Campbell GR: The role of smooth muscle cells in atherosclerosis. Curr Opin Lipidol 1994, 5:323-330

29. Ross R, Glomset JA: The pathogenesis of atherosclerosis (first of two parts). N Engl J Med 1976, 295:369-377

30. Ross R, Glomset JA: The pathogenesis of atherosclerosis (second of two parts). N Engl J Med 1976, 295:420-425

31. Atkinson C, Horsley J, Rhind-Tutt S, Charman S, Phillpotts CJ, Wallwork J, Goddard MJ: Neointimal smooth muscle cells in human cardiac allograft coronary artery vasculopathy are of donor origin. J Heart Lung Transplant 2004, 23:427-435

32. Caplice NM, West MJ, Campbell GR, Campbell J: Inhibition of human vascular smooth muscle cell growth by heparin. Lancet 1994, 344: 97-98

33. Hillebrands JL, Klatter FA, Rozing J: Origin of vascular smooth muscle cells and the role of circulating stem cells in transplant arteriosclerosis. Arterioscler Thromb Vasc Biol 2003, 23:380-387

34. Hirschi KK, Majesky MW: Smooth muscle stem cells. Anat Rec A Discov Mol Cell Evol Biol 2004, 276:22-33

35. Sata M, Maejima Y, Adachi F, Fukino K, Saiura A, Sugiura S, Aoyagi T, Imai $Y$, Kurihara H, Kimura K, Omata M, Makuuchi M, Hirata Y, Nagai R: A mouse model of vascular injury that induces rapid onset of medial cell apoptosis followed by reproducible neointimal hyperplasia. J Mol Cell Cardiol 2000, 32:2097-2104

36. Iwata H, Manabe I, Fujiu K, Yamamoto T, Takeda N, Eguchi K, Furuya A, Kuro OM, Sata M, Nagai R: Bone marrow-derived cells contribute to vascular inflammation but do not differentiate into smooth muscle cell lineages. Circulation 2010, 122:2048-2057

37. Hu Y, Zhang Z, Torsney E, Afzal AR, Davison F, Metzler B, Xu Q: Abundant progenitor cells in the adventitia contribute to atherosclerosis of vein grafts in ApoE-deficient mice. J Clin Invest 2004, 113: 1258-1265

38. Gawaz M, Langer H, May AE: Platelets in inflammation and atherogenesis. J Clin Invest 2005, 115:3378-3384

39. McEver RP: Adhesive interactions of leukocytes, platelets, and the vessel wall during hemostasis and inflammation. Thromb Haemost 2001, 86:746-756

40. Bavry AA, Bhatt DL: Appropriate use of drug-eluting stents: balancing the reduction in restenosis with the concern of late thrombosis. Lancet 2008, 371:2134-2143

41. Laitinen M, Zachary I, Breier G, Pakkanen T, Hakkinen T, Luoma J, Abedi H, Risau W, Soma M, Laakso M, Martin JF, Yla-Herttuala S: VEGF gene transfer reduces intimal thickening via increased production of nitric oxide in carotid arteries. Hum Gene Ther 1997, 8:17371744 